\section{Quantifying Cognitive Dysfunction in COPD: Serum Clusterin Can Be Safely Used as an Alternative Tool to the Questionnaire Based Mental} Assessment

\section{Gupta PR*, Soni S, Singh A, Jagawat T, Jain M, Kumar P, Feroz $A$ and Dawar $S$}

Departments of Respiratory Medicine and Psychiatry, NIMS University, Shobha Nagar, Jaipur, Rajasthan, India

\begin{abstract}
Introduction: This study was undertaken to assess the value of Serum Clusterin (SC) in assessment of Cognitive Dysfunctions (CD) in COPD patients.

Material and methods: All COPD patients and age and sex matched healthy subjects were assessed in detail. They were then subjected to Hindi Mental State Examination (HMSE) in an attempt to assess $\mathrm{CD}$ in them. Their SC levels were also measured using quantitative sandwich enzyme immunoassay technique.

Results: A total of 75 COPD patients and 10 controls could be assessed during the intake period. Fifty four out the 75 COPD patients $(72 \%)$ were detected to have $C D$ on the basis of abnormal HMSE scores $(<25)$. On the other hand CD could be detected in 52 out the 75 COPD patients (69\%) while using SC levels of $>110$ $\mu \mathrm{gm} / \mathrm{ml}$ as criteria for $\mathrm{CD}$. There was an inverse but highly significant correlation between abnormal HMSE scores and SC levels $(p<0.0001)$. Age, sex, duration of illness, the type of smoking, pack years of smoking or Body Mass Index (BMI) poorly correlated to SC levels $(p>0.05)$ but the latter significantly correlated to decreasing PB FEV $1, \mathrm{SPO}_{2}<90 \%(\mathrm{p}<0.001)$ and severity of COPD. History of exacerbations needing hospitalization contributed the most to CD in COPD patients.

Based on these findings it can be concluded that serum SC levels can be safely used to assess CD in COPD patients.

Keywords: Cognitive dysfunctions; COPD; Hindi mental state examination; Serum clusterin
\end{abstract}

*Corresponding author: Prahlad Rai Gupta, Department of Respiratory Medicine, NIMS University, Shobha Nagar, Jaipur, Rajasthan, India, Tel: +91 9414071748; E-mail: Guptapr_dr@hotmail.com

Citation: Gupta PR, Soni S, Singh A, Jagawat T, Jain M, et al. (2016) Quantifying Cognitive Dysfunction in COPD: Serum Clusterin Can Be Safely Used as an Alternative Tool to the Questionnaire Based Mental Assessment J Pulm Med Respir Res 2: 003.

Received: November 20, 2015; Accepted: January 12, 2016; Published: January 27, 2016

\section{Introduction}

Chronic Obstructive Pulmonary Disease (COPD) is defined as a common preventable and treatable disease, characterized by persistent airflow limitation that is usually progressive and associated with an enhanced chronic inflammatory response in the airways and the lung to noxious particles or gases. Exacerbations and comorbidities contribute to the overall severity in individual patients [1]. Systemic inflammation also plays an important role in the severity and the downstream adverse clinical health effects of the disease [2-4].

Cognitive Dysfunctions (CD) in old age COPD patients were first recognised by Chyou et al., [5] but its nature and level were fully described by Borson et al., [6] and Dodd et al., at a later date [7]. Thakur et al., [8] used Mini Mental State Examination (MMSE) to assess CD in COPD patients. A Hindi version of MMSE to assess CD, namely the Hindi Mental State Examination (HMSE) was made available at a later date [9]. However, administrating HMSE is a time consuming affair and is often not feasible in a busy outpatient department. A biochemical parameter to assess $\mathrm{CD}$, therefore, is the need of the hour.

Since Serum Clusterin (SC) was already in use to assess CD in several other diseases, it was reasoned that it could be used in COPD patients also. Li et al., [10] were the first to do so and they found that highest serum clusterin levels were found in severe COPD patients when compared to control subjects. Based on this they advocated the use of SC assays to assess of CD in COPD patients but no further studies are available to substantiate their findings. The present study was therefore undertaken at NIMS Medical College, Jaipur, Rajasthan (India) to know whether SC can be used as an alternative tool to the questionnaire based mental assessment of CD in COPD patients.

\section{Material and Methods}

All the patients reporting at the outpatient department of Respiratory Medicine, NIMS hospital, Jaipur (India) from July 2013 to August 2014 with symptoms suggestive of COPD were recruited for the study. Approval of the Institutional Ethics Committee was obtained. A written informed consent was also taken from all the patients and controls for the study.

All these patients were initially evaluated with a detailed present and past clinical history, comprehensive physical examination and investigations that included total/differential blood counts, erythrocyte sedimentation rate, total eosinophil count, haemoglobin, random blood sugar, urea, creatinine, SGOT/PT, 2 sputa samples for acid fast bacilli by Ziehl Nielsen staining, urine routine examination, $\mathrm{X}$-ray chest posterio-anterior view and a 12 lead electrocardiogram. Spirometry was then performed in sitting position as per American Thoracic Society (ATS) guidelines to measure Forced Vital Capacity (FVC), Forced Expiratory Volume in first second $\left(\mathrm{FEV}_{1}\right)$ and $\mathrm{FEV}_{1} / \mathrm{FVC} \%$, pre and post inhalation of salbutamol $200 \mu \mathrm{g}$. ATS criteria [11] were used to diagnose COPD i.e., Post Bronchodilator Forced Expiratory Volume in $1^{\text {st }}$ second $\left(\mathrm{PB} \mathrm{FEV}_{1}\right)$ of $<80 \%$ of predicted, $\mathrm{FEV}_{1} / \mathrm{FVC}<70 \%$ and $\mathrm{PB}$ improvement in $\mathrm{FEV}_{1}$ of less than $12 \%$ or $200 \mathrm{ml}$. 


\begin{tabular}{|c|c|c|c|c|c|c|}
\hline Parameter & $\begin{array}{l}\text { Category A COPD } \\
\text { patients } \mathrm{N}=19\end{array}$ & $\begin{array}{l}\text { Category B COPD } \\
\text { patients } \mathrm{N}=09\end{array}$ & $\begin{array}{l}\text { Category C COPD } \\
\text { patients } N=16\end{array}$ & $\begin{array}{l}\text { Category D COPD } \\
\text { patients } \mathrm{N}=31\end{array}$ & $\begin{array}{l}\text { Normal subjects } \\
N=10\end{array}$ & $P$ value \\
\hline Mean Age in years & $57.68 \pm 11.73$ & $53.88 \pm 10.14$ & $57.50 \pm 6.27$ & $62.06 \pm 9.35$ & $56.20 \pm 6.76$ & 0.1197 \\
\hline $\begin{array}{l}\text { Sex } \\
\text {-Male } \\
\text {-Female }\end{array}$ & $\begin{array}{l}17 \\
02\end{array}$ & $\begin{array}{l}07 \\
01\end{array}$ & $\begin{array}{l}15 \\
02\end{array}$ & $\begin{array}{l}26 \\
05\end{array}$ & $\begin{array}{l}09 \\
01\end{array}$ & 0.9497 \\
\hline $\begin{array}{l}\text { Mean duration of } \\
\text { illness in years }\end{array}$ & $2.94 \pm 1.79$ & $3.72 \pm 0.52$ & $4.43 \pm 2.19$ & $5.35 \pm 3.26$ & - & 0.0139 \\
\hline $\begin{array}{l}\text { Mean Body Mass } \\
\text { Index in } \mathrm{kg} / \mathrm{M}^{2}\end{array}$ & $19.01 \pm 3.62$ & $19.20 \pm 4.17$ & $19.26 \pm 2.86$ & $18.54 \pm 3.41$ & $19.65 \pm 3.89$ & 0.8968 \\
\hline $\begin{array}{l}\text { Smoking status } \\
\text {-Current } \\
\text {-Ex-smoker }\end{array}$ & $\begin{array}{l}14 \\
05\end{array}$ & $\begin{array}{l}04 \\
05\end{array}$ & $\begin{array}{l}08 \\
08\end{array}$ & $\begin{array}{l}16 \\
15\end{array}$ & - & 0.3359 \\
\hline $\begin{array}{l}\text { Type of smoking } \\
\text {-Bidi } \\
\text {-Other types }\end{array}$ & $\begin{array}{l}17 \\
02\end{array}$ & $\begin{array}{l}08 \\
01\end{array}$ & $\begin{array}{l}14 \\
02\end{array}$ & $\begin{array}{l}25 \\
06\end{array}$ & - & 0.9027 \\
\hline $\begin{array}{l}\mathrm{sPO}_{2} \text { levels in \% } \\
-<90 \\
->90\end{array}$ & $\begin{array}{l}00 \\
19\end{array}$ & $\begin{array}{l}00 \\
09\end{array}$ & $\begin{array}{l}01 \\
15\end{array}$ & $\begin{array}{l}14 \\
17\end{array}$ & - & 0.0001 \\
\hline Mean PB FEV ${ }_{1} \%$ & $63.78 \pm 9.95$ & $61.81 \pm 6.10$ & $38.81 \pm 6.02$ & $37.58 \pm 11.85$ & - & 0.0001 \\
\hline
\end{tabular}

$\mathrm{SPO}_{2}=$ Haemoglobin Saturation in \%; PB FEV $\%$ = Post bronchodilator forced expiratory volume in $1^{\text {st }}$ second of expiration in $\%$

All such diagnosed COPD patients in the age group of 40 to 90 were included in the study but patients with past history suggesting bronchial asthma, other chronic illnesses like malignancy, diabetes mellitus, coronary artery disease, stroke, renal or hepatic disease, injury to head, dementia, sleep disorders, obstructive sleep apnea or psychiatric disorders or exposure to pesticides or toxins were excluded. Ten age and sex matched healthy subjects were also included to serve as controls.

The level of dyspnoea in the study patients was assessed using modified British Medical Research Council (mMRC) questionnaire. The number of exacerbations and number of hospitalizations in the past 3 years, based on history and medical records of the patients, were also recorded. The patients were classed as I to IV on the basis of PB FEV ${ }_{1}$ (GOLD class of severity) and as category A to D on the basis of the combined risk assessment of individual patient [1]. Pulse oximetry was used to evaluate the Oxygenation status $\left(\mathrm{spO}_{2}\right)$ of the patients.

All the subjects were then subjected to HMSE, using 12 items and 23 questions to assess cognitive functions [9]. Venous blood samples were drawn from all of them at around 8.00 AM. The latter were then centrifuged for $20 \mathrm{~min}$ at 3,000 rpm and the supernatants were stored at $-20^{\circ} \mathrm{C}$ but then brought to room temperature for measurement of SC, using quantitative sandwich enzyme immunoassay technique on a commercially available ELISA kit, as per the manufacturer's instructions [12]. Readings were made directly at $450 \mathrm{~nm}$ using Thermo Fisher Scientific Multi scan EX Micro plate Reader.

Since normal range of HMSE scores and SC levels are not available for universal use, the mean of HMSE scores minus twice the Standard Deviation (SD) in normal subjects was used as cut off for abnormal HMSE and the mean of SC levels plus twice the SD in the normal subjects was taken as cut off for abnormal SC levels.

The data so obtained were tabulated and assessed for statistical significance using student's $\mathrm{t}$, Anova, $\mathrm{X}^{2}$, Fisher Exact test as and where applicable. Cramer's $\mathrm{V}$ correlation was used to detect correlation between SC levels and various patient variables. Values of $\mathrm{p}<0.05$ were considered as significant.

\section{Observations}

A total of 75 COPD patients and 10 age and sex-matched controls, could be included in the study during the study period. Nineteen, 09 , 16 and 31 patients were classed as category A, B, C \& D, respectively. The basic parameters of these subjects are shown in table 1 . There were no inter category differences with regard to age, sex or BMI ( $\mathrm{p}$ $>0.1$ ). Most patients were bidi smokers but there were no inter group differences with regard to smoking status, type of smoking or pack years of smoking $(p>0.3)$. The mean duration of illness $(p=0.014)$ and $\mathrm{sPO}_{2} \%<90 \%$ were higher in category $\mathrm{D}$ as compared to the rest $(\mathrm{p}=0.0001)$.

The mean HMSE score in normal subjects was $30.30 \pm 2.68$. Therefore a cut off value for normal subjects was taken as 24.94 i.e., up to 25. Based on abnormal HMSE scores $(<25)$, fifty four out the 75 COPD patients ( $72 \%)$ were diagnosed to have CD, as is shown in table 2. Cognitive dysfunctions were more common in category D patients as compared to the rest (0.00001).

\begin{tabular}{|c|c|c|c|c|c|}
\hline $\begin{array}{c}\text { Cognitive } \\
\text { impairment }\end{array}$ & $\begin{array}{c}\text { Category A } \\
\text { COPD } \\
\text { patients }\end{array}$ & $\begin{array}{c}\text { Category B } \\
\text { COPD } \\
\text { patients }\end{array}$ & $\begin{array}{c}\text { Category C } \\
\text { COPD } \\
\text { patients }\end{array}$ & $\begin{array}{c}\text { Category D } \\
\text { COPD } \\
\text { patients }\end{array}$ & Total \\
\hline $\begin{array}{c}\text { Yes ( HMSE } \\
<25)\end{array}$ & 05 & 07 & 12 & 30 & 54 \\
\hline $\begin{array}{c}\text { No (HMSE } \\
\geq 25)\end{array}$ & 14 & 02 & 04 & 01 & 21 \\
\hline Total & 19 & 09 & 16 & 31 & 75 \\
\hline
\end{tabular}

Table 2: Cognitive impairment in COPD patients based on HMSE score. $X^{2}=48.95 ; p<0.00001$

The mean SC level in normal subjects was $68.10 \pm 21.64 \mu \mathrm{gm} /$ $\mathrm{ml}$. Therefore a cut off value for normal subjects was taken as 110.34 . Table 3 shows the prevalence of CD in different risk groups of COPD patients. Fifty two out the 75 COPD patients (69\%) were diagnosed to 
have CD. Higher number of category D patients suffered from $\mathrm{CD}$ as compared to the rest $(<0.00001)$.

\begin{tabular}{|c|c|c|c|c|c|}
\hline $\begin{array}{c}\text { Cognitive } \\
\text { impairment }\end{array}$ & $\begin{array}{c}\text { Category A } \\
\text { COPD } \\
\text { patients }\end{array}$ & $\begin{array}{c}\text { Category B } \\
\text { COPD } \\
\text { patients }\end{array}$ & $\begin{array}{c}\text { Category C } \\
\text { COPD } \\
\text { patients }\end{array}$ & $\begin{array}{c}\text { Category D } \\
\text { COPD } \\
\text { patients }\end{array}$ & Total \\
\hline $\begin{array}{c}\text { No }(\mathrm{SC}< \\
110)\end{array}$ & 17 & 00 & 06 & 00 & 23 \\
\hline $\begin{array}{c}\text { Yes (SC } \\
>110)\end{array}$ & 02 & 09 & 10 & 31 & 52 \\
\hline Total & 19 & 09 & 16 & 31 & 75 \\
\hline
\end{tabular}

Table 3: Cognitive impairment in COPD patients based on SC levels in $\mu \mathrm{gm} / \mathrm{ml}$.

$X^{2}=48.95 ; p<0.00001$

Table 4 shows the correlation of CD using HMSE score Vis-aVis SC levels. It shows that there was a highly significant correlation between the 2 methods, used for assessment of CD in COPD patients $(<0.0001)$.

\begin{tabular}{|c|c|c|c|}
\hline \multirow{2}{*}{$\begin{array}{c}\text { Cognitive impairment } \\
\text { using HMSE Score }\end{array}$} & \multicolumn{2}{|c|}{$\begin{array}{c}\text { Cognitive impairment } \\
\text { using Sc level }\end{array}$} & \multirow{2}{*}{$\begin{array}{c}\text { Total No. of } \\
\text { patients }\end{array}$} \\
\cline { 2 - 3 } & Yes & No & \\
\hline Yes & 51 & 03 & 54 \\
\hline No & 01 & 20 & 21 \\
\hline Total & 52 & 23 & 75 \\
\hline
\end{tabular}

Table 4: Correlation of cognitive impairment in COPD patients using HMSE Vis-a-vis SC levels.

$X^{2}=57.20 ; p<0.00001$

The correlation between SC levels and various parameters of the study patients are shown in table 5 . Serum clusterin poorly correlated to age, sex, duration of illness, the type of smoking, pack years of smoking or the BMI $(\mathrm{p}>0.05)$ but there was a significant correlation between SC levels and $\mathrm{PB} \mathrm{FEV}_{1}$, different risk categories and $\mathrm{sPO}_{2}$ levels $<90 \%(\mathrm{p}<0.001)$.

\begin{tabular}{|c|c|c|c|}
\hline \multicolumn{2}{|c|}{ Parameter } & \multirow{2}{*}{$\begin{array}{c}\text { Mean SC in } \boldsymbol{\mu g m} / \mathbf{m l} \\
118.01 \pm 37.60 \\
141.62 \pm 53.54 \\
143.15 \pm 36.90\end{array}$} & \multirow{2}{*}{$\begin{array}{r}\text { P value } \\
0.579\end{array}$} \\
\hline Age in years & $\begin{array}{l}\leq 50 \\
51-60 \\
>60\end{array}$ & & \\
\hline Sex & $\begin{array}{l}M \\
F\end{array}$ & $\begin{array}{l}137.73 \pm 41.05 \\
126.63 \pm 34.11\end{array}$ & 0.951 \\
\hline Total duration in years & $\begin{array}{l}<3 \\
3-5 \\
>5\end{array}$ & $\begin{array}{l}122.82 \pm 36.72 \\
141.37 \pm 53.14 \\
155.96 \pm 29.66\end{array}$ & 0.0776 \\
\hline Pack years of smoking & $\begin{array}{c}<30 \\
30-40 \\
>40\end{array}$ & $\begin{array}{l}110.56 \pm 35.73 \\
143.40 \pm 51.57 \\
139.82 \pm 41.00\end{array}$ & 0.1861 \\
\hline Body Mass Index & $\begin{array}{c}<18 \\
18-22 \\
>22\end{array}$ & $\begin{array}{l}141.52 \pm 46.95 \\
128.23 \pm 41.56 \\
131.21 \pm 41.47\end{array}$ & 0.7521 \\
\hline $\mathrm{sPO}_{2} \%$ & $\begin{array}{l}<90 \\
>90\end{array}$ & $\begin{array}{l}128.48 \pm 45.78 \\
167.25 \pm 23.76\end{array}$ & 0.0009 \\
\hline PB FEV ${ }_{1} \%$ & $\begin{aligned} & \geq 50 \\
\geq & 30-<50 \\
& <30\end{aligned}$ & $\begin{array}{l}110.65 \pm 35.38 \\
156.15 \pm 44.86 \\
156.78 \pm 31.61\end{array}$ & 0.0010 \\
\hline Risk category & $\begin{array}{l}\text { A } \\
B \\
C \\
D\end{array}$ & $\begin{array}{c}86.54 \pm 17.22 \\
128.43 \pm 9.77 \\
123.25 \pm 27.73 \\
175.62 \pm 33.63\end{array}$ & 0.0001 \\
\hline
\end{tabular}

Table 5: Correlation of SC levels with various parameters of the COPD patients.

$\mathrm{sPO}_{2}=$ Haemoglobin Saturation in \%; PB FEV $\%=$ Post bronchodilator forced expiratory volume in $1^{\text {st }}$ second of expiration in $\%$
Since mean SC levels were similar in category B (128.43 \pm 9.77 $\mu \mathrm{gm} / \mathrm{ml})$ and category $C$ patients $(123.25 \pm 27.73 \mu \mathrm{gm} / \mathrm{ml})$ of this study, the individual parameters used in the combined risk assessment of COPD were also correlated to SC levels. There was a significant and direct correlation between SC levels and hospitalizations per year, exacerbations per year, mMRC and GOLD class $(p<0.0001)$ in that order, the respective correlation coefficient $\left(\mathrm{r}^{\mathrm{s}}\right)$ being $0.852,0.811$, 0.739 and 0.519 .

\section{Discussion}

Cognitive dysfunctions were recorded in as high as $72 \%$ COPD patients of this study. Several others have also noted CD in good number of COPD patients [5-8]. Further, CD increased with an increase in severity of COPD as HMSE scores were the highest in category A and lowest in Category D patients $(\mathrm{p}<0.0001)$. Most patients in risk category D had HMSE score $<20$ but most patients in risk category A had HMSE scores $>25$. A significant inverse correlation was also found between $\mathrm{PB} \mathrm{FEV}_{1}$ and $\mathrm{CD}(\mathrm{p}<0.001)$ in this study. Chyou et al., [5] and Schou et al., [13] also observed an inverse correlation between cognitive functions and severity of COPD as measured by pulmonary functions but Thakur et al., [8] did not find any correlation between most of the severity measures of COPD and the risk of cognitive impairment $(P>0.20)$. Several others have also noted that pulmonary functions by itself are poor predictors of CD [14-16]. The reasons behind this difference are not fully known but oxygen saturation vis-a-vis pulmonary functions could have been different in different studies. Several workers including Thakur et al., [8] and Li et al., [10] could note a direct correlation between cognitive functions and $\mathrm{PaO}_{2}$. In our study also, HMSE scores were significantly lower in patients having $\mathrm{sPO}_{2}<90 \%$ as compared to the rest, retreating that oxygenation status in the COPD patients have a definitive bearing on $\mathrm{CD}$ in them.

The mean SC level in normal subjects was $68.10 \pm 21.64 \mu \mathrm{gm} / \mathrm{ml}$ in this study. Based on abnormal SC levels (>110 $\mu \mathrm{gm} / \mathrm{ml}), \mathrm{CD}$ was detected in 52 patients $(69 \%)$ using abnormal SC levels. Further, a significant but an inverse correlation was found between HMSE score and SC levels. This shows that SC levels can be safely used as an alternative to the questionnaire based mental assessment in COPD patients as has been recommended earlier by Lie et al., [10].

As expected and in line with observations made earlier [10], the mean SC levels correlated poorly to age, sex and duration of illness, type of smoking or pack years and BMI of the study patients but it significantly correlated to PB FEV $1(\mathrm{p}<0.001)$ and $\mathrm{SPO}_{2}(\mathrm{p}<0.001)$. Most patients in category A had mean SC levels near to the normal and most patients in category D had abnormal values of SC. In fact, the mean SC values were significantly higher in category $\mathrm{D}$ patients as compared to the rest $(\mathrm{p}<0.0001)$ but the mean SC levels were similar for category B and C patients of our study. Detailed analysis revealed that there exists a direct correlation between SC levels and various risk factors used in categorization of COPD patients. However, the degree of significance varied and $r^{s}$ for hospitalizations per year, exacerbations per year, mMRC and GOLD class were $0.852,0.811$, 0.739 and 0.519 in that order. Thus, all the risk factors contribute to cognitive impairment in COPD but exacerbations needing hospitalization contribute the most. This, in all probabilities, is due to repeated occurrence of desaturations during exacerbations, an important risk factor for $\mathrm{CD}$. This has not been observed by any of the studies done earlier.

In conclusion, most COPD patients, more particularly the high risk category D patients, suffer from $\mathrm{CD}$ and exacerbations needing 
hospitalization and falling $\mathrm{SPO}_{2}$ are the most important risk factors for $\mathrm{CD}$. Estimation of $\mathrm{SC}$ in serum of these patients is a useful peripheral biomarker for assessment of $\mathrm{CD}$ in them as it obviates the time consuming questionnaire based assessment. The major limitation of the study is the smaller number of patients and larger studies are required to further reiterate the findings of this study.

\section{References}

1. Global Initiative for Chronic Obstructive Pulmonary Disease (2015) Global Strategy for Diagnosis, Management and Prevention of COPD.

2. van Eeden SF, Sin DD (2008) Chronic obstructive pulmonary disease: a chronic systemic inflammatory disease. Respiration 75: 224-238.

3. Barnes PJ, Celli BR (2009) Systemic manifestations and comorbidities of COPD. Eur Respir J 33: 1165-1185.

4. Cazzola M, Bettoncelli G, Sessa E, Cricelli C, Biscione G (2010) Prevalence of comorbidities in patients with chronic obstructive pulmonary disease. Respiration 80: 112-119.

5. Chyou PH, White LR, Yano K, Sharp DS, Burchfiel CM, et al. (1996) Pulmonary function measures as predictors and correlates of cognitive functioning in later life. Am J Epidemiol 143: 750-756.

6. Borson S, Scanlan J, Friedman S, Zuhr E, Fields J, et al. (2008) Modeling the impact of COPD on the brain. Int J Chron Obstruct Pulmon Dis 3: 429-434.

7. Dodd JW, Getov SV, Jones PW (2010) Cognitive function in COPD. Eur Respir J 35: 913-922.
8. Thakur N, Blanc PD, Julian LJ, Yelin EH, Katz PP, et al. (2010) COPD and cognitive impairment: the role of hypoxemia and oxygen therapy. Int J Chron Obstruct Pulmon Dis 5: 263-269.

9. Ganguli M, Ratcliff G, Chandra V, Sharma S, Gilby JE, et al. (1995) A Hindi version of the MMSE: the development of a cognitive screening instrument for a largely illiterate rural elderly population in India. International Journal of Geriatric Psychiatry 10: 367-377.

10. Li J, Huang Y, Fei GH (2013) The evaluation of cognitive impairment and relevant factors in patients with chronic obstructive pulmonary disease. Respiration 85: 98-105.

11. Celli BR, MacNee W, ATS/ERS Task Force (2004) Standards for the diagnosis and treatment of patients with COPD: a summary of the ATS/ERS position paper. Eur Respir J 23: 932-946.

12. Quantikine ELISA (2013) Mouse Clusterin Immunoassay, Catalog Number MCLU00. R\&D Systems, Inc. Pg no: 1-14.

13. Schou L, Østergaard B, Rasmussen LS, Rydahl-Hansen S, Phanareth $\mathrm{K}$ (2012) Cognitive dysfunction in patients with chronic obstructive pulmonary disease--a systematic review. Respir Med 106: 1071-1081.

14. Etnier J, Johnston R, Dagenbach D, Pollard RJ, Rejeski WJ, et al. (1999) The relationships among pulmonary function, aerobic fitness, and cognitive functioning in older COPD patients. Chest 116: 953-960.

15. Antonelli-Incalzi R, Imperiale C, Bellia V, Catalano F, Scichilone N, et al. (2003) Do GOLD stages of COPD severity really correspond to differences in health status? Eur Respir J 22: 444-449.

16. Liesker JJ, Postma DS, Beukema RJ, ten Hacken NH, van der Molen T, et al. (2004) Cognitive performance in patients with COPD. Respir Med 98: 351 356. 